\title{
Study Subject Type Code
}

National Cancer Institute

\section{Source}

National Cancer Institute. Study Subject Type Code. NCI Thesaurus. Code C93685.

A coded value specifying the targ et entity of the study of investigation. 